\title{
PERCEPTIONS AND OPINIONS OF GRADUATES ABOUT THE EFFECTS OF OPEN AND DISTANCE LEARNING IN TURKEY
}

\author{
Dr. Betul KAN KILINC \\ ORCID: 0000-0002-3746-2327 \\ Faculty of Science \\ Eskisehir Technical University \\ Eskisehir, TURKEY \\ Dr. Berna YAZICI \\ ORCID: 0000-0001-9843-7355 \\ Faculty of Science \\ Eskisehir Technical University \\ Eskisehir, TURKEY \\ Dr. Bulent GUNSOY \\ ORCID: 0000-0001-6370-189X \\ Faculty of Economics \\ Anadolu University \\ Eskisehir, TURKEY \\ Dr. Guler GUNSOY \\ ORCID: 0000-0002-0104-9784 \\ Faculty of Economics \\ Anadolu University \\ Eskisehir, TURKEY
}

Received: 15/02/2019 Accepted: 28/05/2019

\begin{abstract}
Open and distance learning in higher education provides an opportunity to individuals who cannot attend university full time on campus. Urban area residents especially have an advantage by accessing such higher education. There are almost three million people who receive university education in this way, and almost 1,5 million students in the Open and Distance Learning System at Anadolu University. On campus university graduates can also register for any department as a second university to receive university education in the Open and Distance Learning System. Therefore, the number of students and graduates increase every year. The purpose of this study is to analyze the role of the Open and Distance Learning System at Anadolu University, which has helped Turkish higher education by means of increasing economic and social welfare. To achieve the goal, 9131 graduates were surveyed. The results indicate that the Open and Distance Learning System in question has been effective with regard to their employment status (before and after education), income levels and their social-economic welfare positions.
\end{abstract}

Keywords: Educational leaders, educational policy, distance education, distance learning, opinions of graduates.

\section{INTRODUCTION}

The education process, with its multi-dimensional presence is, perhaps, the most important tool in determining a society's progress. Education contributes to people's well-being not only by direct-financial dimensions, but also by indirect-moral ways. It is a clear fact that a society of happier people would inevitably achieve a better social welfare level. Education makes people healthier, reduces poverty, makes income distribution better, increases productivity by elevating the technology level and creates a free path for growth and employment. 
For these reasons, education is not limited to youth, as it used to be, and lifelong learning is in great demand by countries throughout the world. Both compulsory and optional education are continuously diversifying, they are becoming independent from time and place and they are moving away from conventional forms of education. In this context, being parallel with advances in communication and information technologies, Open and Distance Learning (ODL) Systems were always likely to be investigated more than ever. These Open and Distance Learning Systems are important processes which help increase human capital in order to achieve higher economic and social welfare.

\section{THE EFFECTS OF EDUCATION TO INDIVIDUAL AND NATIONAL INCOME}

The most important dimension of education is, perhaps, its individual and macro-economic effects. There is compelling evidence implying that investment in education affects economic growth, both directly and indirectly, which causes increases in earnings. One of the most important models used in studies in this area is Mincer's model (1974). He sees individual income as a function of education, experience and practice, and this model pioneered many studies after him. Possibly the very first empirical study in this field, Aukrust and Bjerke (1995), show that investments for education in Norway increased economic growth by $1,81 \%$ (Tilak, 1989). Schultz (1961a, 1961b) and Denison (1962) showed similar findings in their studies. Heckman and Klenow (1997) found that each additional year of education increases income per capita by 30\%, Bassanini and Scarpetta (2001) and Sianesi and van Reenen (2003) postulate that an increase in average education of one year increases income per capita by between 3\% and 6\%. Gennaioli et al. (2013) found that for 97\% of the world, each additional year of education increases income per capita by $26 \%$. Breton (2003) claims that between 1950 and 1985, for 61 countries, national outputs increased due to increases in the productivity of education due to investments in education. Breton (2014) shows that an increase in average education by one year causes an increase in national income of $10 \%$ directly and $19 \%$ indirectly. In addition, there are interesting results from studies that imply primary enrollment to be more effective for emerging markets and higher education to be more effective for developed countries; as Mingat and Tan (1996). Bassanini and Scarpetta (2001) propose that, for OECD countries, an increase in education by one year increases productivity by $6 \%$. While Ferreira and Litchfield (1998) reveal that between a $25 \%$ and $30 \%$ increase in income per capita in Chile was caused by an increase in educational attainment, Orazem, Glewwe and Patrinos (2007) show that, with a productivity increase in rural areas, poverty rates declined. Polachek (2007) and Davies (2003) show that human capital and investments in education cause increases in income levels. Known for his research into the relationship between education and the economy, Schultz, does not see any difference between institutions of education and institutions of industrial production.

\section{THE EFFECTS OF EDUCATION TO INDIVIDUAL AND SOCIAL WELFARE}

It is thought that the process of education has a positive effect on individual and social welfare and happiness. Happiness and welfare are hard-to-measure factors due to their highly subjective construct. However, welfare mostly concerns financial life. Issues such as income, health, employment, earnings, and shelter are all parts of welfare since a lack of any causes sadness. Health, work and life balance, education, experience, social relations, civil life and governance, environmental quality, self-security and other subjective welfare proxies constitute the main dimensions of individual and social welfare. At this point, amongst all these factors, education is one of the most important concepts. In other words, education is a key factor and a common ground for all other factors of social welfare.

Education creates a suitable social and cultural platform for development by changing individual and group behavior. By doing this, while cultivating stability, education acts as a catalyst that creates social dynamism for socio-economic evolution. One pioneering study on this topic is Becker's paper (1993), which implies that by an increase in educational attainment, there is an increase in voting activity, artistic and sporting activities, a decrease in smoking and an upswing in health conditions. There are also empirical studies that show education decreases crime rates. On the other hand, there are studies that show that an increase in education creates social income inequality and poverty. For example, Adelman and Morris (1973) show the positive effects of human capital on income distribution. Psacharopoulos (1977) shows that for 49 
countries, education explains $23 \%$ of income inequality, a result which is proxied by the Gini coefficient. Psacharopoulos and Ying Chu (1992) show that with increased education, income inequality and poverty in eighteen countries located in Latin America decreased. Patrinos and Psacharopoulos (2011) imply that each additional year of education causes a decrease in the Gini coefficient by 1.4 points. Tsakloglou and Cholezas (2005) proved that education (especially higher education) in Greece causes a decrease in inequality. Bourguignon (1995) and Bourguignon and Morrison (1990) argue that secondary education, to a degree, has a remedial effect on income distribution. There is much empirical evidence for education having positive effects on environmental consciousness, social unity, rates of saving, the health of mothers, their children and babies, and families generally, as well as technological progress (2001).

\section{ECONOMICAL AND SOCIAL RETURNS OF OPEN AND DISTANCE LEARNING}

The methods of open and distance learning play important roles, especially with regard to populous countries' educational needs. This is because generalizing formal education at a country level is a costly and timeconsuming process. At this point, open and distance learning may be seen as a useful choice. In countries where open and distance learning is handled strategically and systematically, the operation easily reaches large masses. In this context, previous positive effects of education on social welfare may also be approved for open and distance learning. At this point, the first thing that comes to mind is people in work who benefit from open and distance learning could directly increase their individual welfare and life standards. After completing their education with more possibilities, such as finding new work, gaining promotion, and gaining wage increases, it is natural that they enjoy an increased level of welfare. In addition, open and distance learning could help people beyond financial considerations. The process of education may make people more conscious. Learners may become more conscious consumers and become healthier.

Studies that examine the effects of open and distance learning on economic and social welfare are relatively rare. Actually, in general, formal education and open and distance learning methods are approached in unison. Studies in this field are generally centered on gender, and specifically on the effects of open and distance learning on women's educational attainment and its advantages. For instance; Ambe-Uva (2010) studied the ODL system's contribution to poverty alleviation and the empowerment of women. Adewara et al. (2010) researched the performance of distance learning and full-time students. These two studies show the effect of ODL in Nigeria as a developing country.

Sahin and Shelly (2008) measured Distance Education students' perceptions and constructed a satisfaction model using structural equation models. Holzweiss et al. (2014) also studied perceptions of online graduate students' in their paper. There have been studies which show the use of technology in distance education, besides their benefits from ODL, such as that of Tatar et al. (2015), Simsek (2005), Remedios and Richardson (2013). In addition, student contact with universities in the distance learning system has been put into question by Shea et al. (2015) and Moore (2011).

Khan and Williams (2007) suggest that e-learning platforms are powerful tools for decreasing poverty and increasing the social welfare of disadvantaged groups (people on low income, the disabled, the long-term ill, minorities, and suchlike). Open and distance learning systems also have positive effects on income and poverty. Ferdousi (2010) points out that official distance education institutions have positive effects on gender inequality in Bangladesh and remarks that the Open University in Bangladesh creates opportunities for both adults and women by enabling them to study while working. Ofoegbu (2009), like Ferdousi (2010), emphasizes that open and distance learning systems provide women with primary education, thus decreasing gender inequality. In field research in Benin, Edo/Nigeria, it has been shown that open and distance learning has a significant positive impact on female enrollment rates, thus providing women with the same opportunities as men. The author of the study proposes that with such a system women could be able to continue engaging in income generating activities. Aderinoye and Ojokheta (2004) elaborate the effect of open and distance learning on sustainable development. The study, which points out the effects of open and distance learning on individual, social and national development, was carried out in Nigeria. The study, carried out using surveys, interviews and personal interaction, shows that distance education increases the number of choices people have, gives them awareness of current and future opportunities and, thereby, achieves a sustainable development continuum. Ambe-Uva and Adegbola (2009) studied the effects of open and distance learning 
on Africa's social upheaval, poverty, conflict areas, marginalization and achieving the objectives of human development in Nigeria. The authors claim that the integrative power of open and distance learning and ICTs provide people with income and, thus, indirectly increase human security and decreases the spread of diseases, such as HIV/AIDS. Ghadoliya (2012), who argues that education is the most powerful power freeing agent, claims that Indian women enjoy an increase in their income through micro-finance, but that they lack the required banking or accounting skills, and that open and distance learning plays an important role filling the gap, thereby enabling them to perform better in their jobs. A study edited by Kanwar and Taplin (2001) was conducted in different countries and consists of case studies. In these studies, certain common conclusions were arrived at. These are that through distance education methods, women and mothers become of more assistance to their husbands, children and other family members without having to go far from home. Distance education also increases women's self-care. Distance education helps children and eases their suffering. Through distance education, children are able to remain at home with their mothers. With distance education, women are more able to cope with their fears, and share their experiences and coping skills with others. Olakulein (2006) discusses the role of distance education in the empowerment of women. Starting from the results of research conducted in Nigeria, Olakulein (2006) points out that distance education is not only an efficient way of education, but is also relatively inexpensive, thereby significantly helping women whose reading rates and subsistence levels are highly disadvantageous. Arguing that a qualifying distance education system could save women and families from poverty, Olakulein (2006) stresses that, through education, social life may become possible and that contagious diseases may even decrease.

\section{PURPOSE OF THE STUDY}

The purpose of this study is to analyze the role of the Open and Distance Learning System at Anadolu University, which has helped Turkish higher education by means of increasing economic and social welfare. To achieve the goal, a survey study was conducted to alumni who had graduated from the Anadolu University Open and Distance Learning Faculty.

To investigate whether ODL help increase human capital and make income distribution better and achieve a better social welfare level or not, a questionnaire was constructed to compare the situations of the students before and after graduation.

The three main research questions are as follows:

1. Is there any difference difference between the earnings of graduates before and during the program?

2. Is there any differences difference between the earnings of graduates during and after the program?

3. Is there any difference difference between the earnings of graduates before and after the program?

Hence, the employment status (before, during and after education), income levels and social-economic welfare situations were determined. Also the opinions and perceptions of graduates on ODL system were examined and finally it was tested that if the difference on opinions were depending on gender or not.

\section{METHOD}

A questionnaire was constructed to compare the situations of the students before and after graduation. Overall Interval Realibility was determined as 0.87 . Firstly, the demografic situation of the participants were given. The data obtained from the survey were analysed. To do so, t-tests, Chi-square tests were conducted and the results were summarized in the tables.

\section{Participants}

The population was constructed with 852,730 graduates who had graduated from three different faculties of the Anadolu University Open and Distance Learning Faculty between 2000 and 2009. Data collection was provided by an online questionnaire consisting 39 questions. The graduates were contacted through the ODL automation system via email and asked to participate in the questionnaire using their ODL accounts. Therefore, the 9131 respondents to the questionnaire were accessed by the Anadolu University Alumni Union. 


\section{Data Collection and Analysis}

The data collected by randomly included some items for the participants to evaluate the percentage of their answers regarding the ODL system. At the first part of the questionnaire form the demographic questions were asked to the respondents. The second part of the questionnaire consisted of fourteen questions in order to determine the socio-economic situations of the graduates. The last part was consisted of eighteen questions of Type Likert that were about the perceptions of the graduates. At this part, the participants were asked to use one of five different terms to express their thoughts whilst completing the questionnaire; definitely disagree (scored 1), partially disagree (scored 2), neutral (scored 3), partially agree (scored 4), and strongly agree (scored 5). As a result, they indicated the extent of their agreement or disagreement with the relevant statement on a five-point Likert scale.

The questions were not only related to the economic situations of the respondents but also they were about the social lives of them. The survey was conducted using the internet. The graduates were asked to complete the questionnaire within a certain time by email. SPSS 20.0 and R were used to analyze the dataset.

\section{FINDINGS}

The data consists of questionnaire forms from 9131 respondents who graduated from three different faculties; the Economics Faculty, the Business Faculty and the Open Education Faculty, of the Open and Distance Learning System at Anadolu University. The age distribution of the graduates is given in Figure 1.

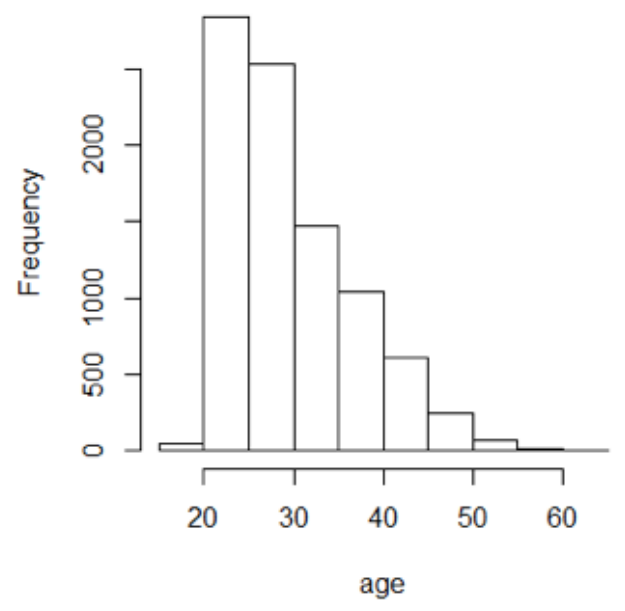

Figure 1. Age distribution of respondents.

The graduates were asked if they would have had a chance to attend university if they had not attended distance education. The results show that many of the respondents, particularly those from urban areas, would not have been able to attend university. The gender distribution of the answers to this question is shown in Table. 1.

Table 1. The gender distribution of respondents in regard to 'having a chance to attend university'.

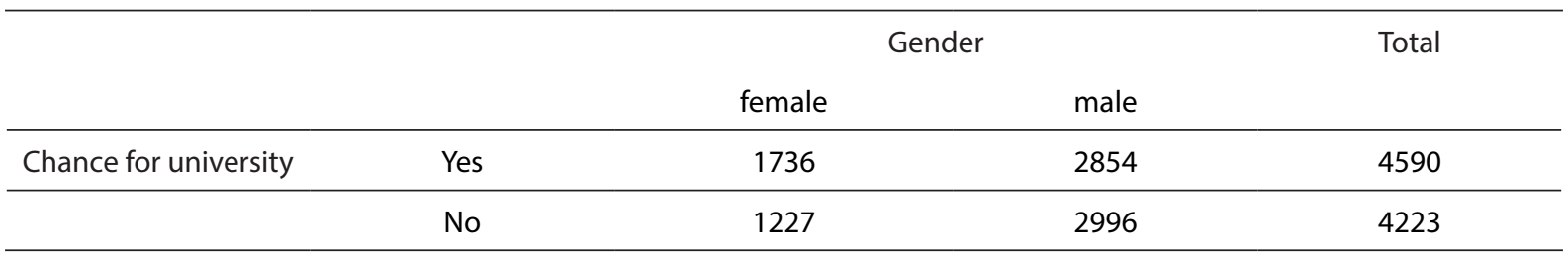


Explanations related to the economic welfare of graduates are summarized with three questions in the data collection. It is believed that the welfare of graduates of the Open and Distance Learning System at Anadolu University significantly changes following the program. For this purpose, the graduates were asked to compare their earnings before, during and after the program. Dependent sample t-tests for paired samples were used to test the research questions and the results are given in Table 2.

Table 2 shows the t-test results for the main three questions. The first research question is about whether there was any significant difference between the earnings of graduates before and during the program. According to the results it essentially shows that the Open and Distance Learning System at Anadolu University was effective on the previous and the current earnings of graduates at that time $(\mathrm{p}=0.000)$.

The second research question is about whether there was any significant difference between the earnings of graduates during and after the program. The results show that the Open and Distance Learning System at Anadolu University was effective on the current and the post-earnings of graduates $(\mathrm{p}=0.000)$.

The third research question is about whether there was any significant difference between the earnings of graduates before and after the program. The results show that the Open and Distance Learning System at Anadolu University was effective pre-earnings and the post-earnings of graduates.

Overall, all of the questions are rejected at a 5\% significance level showing that there was some evidence to suggest the Open and Distance Learning System at Anadolu University did have an impact on graduate earnings.

Table 2. t-test results: The earnings of graduates before and after education

\begin{tabular}{|c|c|c|c|c|c|}
\hline Statement & Mean & $\begin{array}{c}\text { Std. } \\
\text { Deviation }\end{array}$ & t-value & $\begin{array}{l}\text { Degrees of } \\
\text { freedom }\end{array}$ & $p$-value \\
\hline $\begin{array}{l}\text { The earnings of graduates before and during the program } \\
\text { in the Open and Distance Education Learning System did } \\
\text { not change. }\end{array}$ & -0.50290 & 1.21800 & -36.356 & 7752 & 0.000 \\
\hline $\begin{array}{l}\text { The earnings of graduates during and after the program in } \\
\text { the Open and Distance Education Learning System did not } \\
\text { change. }\end{array}$ & -0.39803 & 1.46264 & -24.059 & 7815 & 0,000 \\
\hline $\begin{array}{l}\text { The earnings of graduates before and after the program in } \\
\text { the Open and Distance Education Learning System did not } \\
\text { change. }\end{array}$ & -0.34603 & 2.00753 & -16.309 & 8952 & 0,000 \\
\hline
\end{tabular}

It is reasonable to expect that the Open and Distance Learning System has impact on the life quality of graduates. The key focus is to identify if there is any contribution of the Open and Distance Learning System in providing graduates with a better life of quality. Therefore, in this part of the study regarding to the life of quality, the relationship among four selected questions are examined: the gender of participant; the status of the graduates when they were in the program; having an opportunity to study at any other university; and finding work after graduation from the Open and Distance Learning System. The four selected statements are tested using a chi-square test of independence. Table. 3 provides the results of the chi-square tests.

The first statement is about whether 'the status of receiving income whilst on the program' and 'the gender of graduates' were independent. A chi-square test of independence of the relationship between the status of receiving income whilst on the program and the gender of graduates finds a statistically significant relationship between these statements (chi-square $=367.070, \mathrm{p}=0.000$ ). Table 3 shows the amount of difference needed to make a decision based on the probabilities given in the table. As $\mathrm{p}=0.000$ for the first test, this means that the status of receiving income whilst on the program and the gender of graduates are not statistically independent. This value is equal to also testing for the second and third statements in Table. 3. Hence, based on the probability $(\mathrm{p}=0.000)$, the relationship between 'gender' and 'having an opportunity to study at any other university' is not statistically independent. Moreover, the relationship between 'gender' and 'finding work after graduation from the Open and Distance Learning System' is also statistically significant. Finally, relationship between 'the faculty' and 'finding work after graduation from the Open and Distance Learning System' is 
not statistically independent at a 0.05 significance level. The probability of the chi-square test statistic (chisquare $=10.530$ ) was $\mathrm{p}=0.005$ that was lower than the significance level. Therefore, the faculty graduated from the Open and Distance Learning System is statistically dependent with regard to finding work.

Table 3. Pearson Chi-Square Results

\begin{tabular}{lccc}
\hline \multicolumn{1}{c}{ Statement } & Value & $\begin{array}{c}\text { Degrees of } \\
\text { freedom }\end{array}$ & p-value \\
\hline $\begin{array}{l}\text { No significant linear relationship between the gender and the status of } \\
\text { graduates whilst on the program. }\end{array}$ & 367.070 & 1 & 0.000 \\
$\begin{array}{l}\text { No significant linear relationship between gender and having an } \\
\text { opportunity to study at any other university has not changed. }\end{array}$ & 75.734 & 1 & 0.000 \\
$\begin{array}{l}\text { No significant linear relationship between gender and finding work after } \\
\text { graduation from the Open and Distance Education Learning System has } \\
\text { not changed. }\end{array}$ & 561.960 & 2 & 0.000 \\
$\begin{array}{l}\text { Any significant linear relationship between the faculty and finding work } \\
\text { after graduation from the Open and Distance Education Learning System } \\
\text { has not changed. }\end{array}$ & 10.530 & 2 & 0.005 \\
\hline
\end{tabular}

In Table 4, the percentages of the contributions based on a Likert type for the statements listed from 1 to 9 are given.

Generally, the percentage of the 'strongly agree' respondents is higher than the percentage of the 'definitely disagree' respondents in all of the items except for the first and the last. This finding may be interpreted in such a way that graduates from the ODL system already had a say in their own families and an active social life involving 'seeing experience (Simsek, 2005), such as excursions, journeys, theatre, cinema and so on', regardless of the ODL system.

Table 4. Percentage of contributions

\begin{tabular}{|c|c|c|c|c|c|c|c|}
\hline & Statement & $\begin{array}{c}\text { Definitely } \\
\text { Disagree (\%) }\end{array}$ & $\begin{array}{l}\text { Partially } \\
\text { Disagree } \\
\text { (\%) }\end{array}$ & $\begin{array}{l}\text { Neutral } \\
(\%)\end{array}$ & $\begin{array}{l}\text { Partially } \\
\text { Agree (\%) }\end{array}$ & $\begin{array}{l}\text { Strongly } \\
\text { Agree (\%) }\end{array}$ & $\begin{array}{l}\text { No. of } \\
\text { respondents / } \\
\text { participants }\end{array}$ \\
\hline 1 & $\begin{array}{l}\text { Having more of a say in the } \\
\text { family than before }\end{array}$ & 25.3 & $\begin{array}{c}17.5 \\
(1445)\end{array}$ & $\begin{array}{c}12.6 \\
(1036)\end{array}$ & 22.4 & 22.2 & $8245 / 9131$ \\
\hline 2 & Finding a place in society & $\begin{array}{c}13.6 \\
(1055)\end{array}$ & $\begin{array}{c}14.1 \\
(1097)\end{array}$ & $\begin{array}{l}11.2 \\
(865)\end{array}$ & $\begin{array}{c}27.4 \\
(2122)\end{array}$ & $\begin{array}{c}33.8 \\
(2618)\end{array}$ & $7757 / 9131$ \\
\hline 3 & Building greater self-esteem & $\begin{array}{l}12.7 \\
(976)\end{array}$ & $\begin{array}{c}8.5 \\
(656)\end{array}$ & $\begin{array}{c}8.8 \\
(677)\end{array}$ & $\begin{array}{c}22.1 \\
(1705)\end{array}$ & $\begin{array}{c}47.9 \\
(3694)\end{array}$ & $7708 / 9131$ \\
\hline 4 & $\begin{array}{l}\text { Awareness of social } \\
\text { responsibility }\end{array}$ & $\begin{array}{c}14.6 \\
(1123)\end{array}$ & $\begin{array}{r}10.8 \\
(834)\end{array}$ & $\begin{array}{l}11.8 \\
(893)\end{array}$ & $\begin{array}{c}26.8 \\
(2062)\end{array}$ & $\begin{array}{c}36.3 \\
(2796)\end{array}$ & $7708 / 9131$ \\
\hline 5 & $\begin{array}{l}\text { Awareness of individual rights } \\
\text { and responsibilities }\end{array}$ & $\begin{array}{c}14.5 \\
(1107)\end{array}$ & $\begin{array}{l}10.3 \\
(786)\end{array}$ & $\begin{array}{l}11.2 \\
(851)\end{array}$ & $\begin{array}{c}26.9 \\
(2049)\end{array}$ & $\begin{array}{c}37.1 \\
(2829)\end{array}$ & $7622 / 9131$ \\
\hline 6 & $\begin{array}{l}\text { Providing business } \\
\text { development }\end{array}$ & $\begin{array}{l}11.8 \\
(899)\end{array}$ & $\begin{array}{c}9.8 \\
(746)\end{array}$ & $\begin{array}{l}11.8 \\
(899)\end{array}$ & $\begin{array}{c}26.9 \\
(2045)\end{array}$ & $\begin{array}{c}39.6 \\
(3014)\end{array}$ & $7603 / 9131$ \\
\hline 7 & $\begin{array}{l}\text { Increasing opportunities for } \\
\text { work in everyday life }\end{array}$ & $\begin{array}{l}12.2 \\
(925)\end{array}$ & $\begin{array}{c}9.7 \\
(739)\end{array}$ & $\begin{array}{l}12.5 \\
(953)\end{array}$ & $\begin{array}{c}27.2 \\
(2063)\end{array}$ & $\begin{array}{c}38.4 \\
(2916)\end{array}$ & $7596 / 9131$ \\
\hline 8 & Promotion at work & $\begin{array}{c}23.3 \\
(1700)\end{array}$ & $\begin{array}{c}9.3 \\
(682)\end{array}$ & $\begin{array}{c}17.8 \\
(1297)\end{array}$ & $\begin{array}{c}18.9 \\
(1375)\end{array}$ & $\begin{array}{c}30.7 \\
(2244)\end{array}$ & $7298 / 9131$ \\
\hline 9 & $\begin{array}{l}\text { Cultural activities, such as } \\
\text { excursions, journeys, theatre, } \\
\text { cinema and so on }\end{array}$ & $\begin{array}{c}37.6 \\
(2742)\end{array}$ & $\begin{array}{l}13.3 \\
(968)\end{array}$ & $\begin{array}{c}19.0 \\
(1386)\end{array}$ & $\begin{array}{c}15.7 \\
(1146)\end{array}$ & $\begin{array}{c}14.4 \\
(1046)\end{array}$ & $7289 / 9131$ \\
\hline
\end{tabular}

(): refers to the number of respondents 
It is clear from the table that the greatest contribution of the ODL system to graduates' lives is seen with $47.9 \%$ (almost half of the respondents) for item 3 which states that the ODL system helps them build more self-esteem. The second highest percentage is found as $39.6 \%$ for item 5 , stating that having a knowledgeable background provides business development. Item 7 is also high (38.4\%), stating that a degree from the ODL system widens the range of job opportunities in everyday life. The situation for item 8 is also notable, stating that $30 \%$ of respondents enjoyed promotion in business after their graduation from the ODL system.

In Turkey, especially in urban areas, considerations regarding importance may vary due to gender. As a result, comparisons due to gender increase in importance.

At this part of the study, the responses were compared according to the gender of the respondents for the eighteen items in question. The statements in question and the $t$ test results based on the thoughts of the gender of the respondents were summarized in Table 5.

Table 5. The $t$ tests of gender for eighteen questions

\begin{tabular}{llll}
\hline Statement & Female & Male & $\mathrm{P}$ \\
\hline 1. Contribution in family & 3.09 & 2.93 & .000 \\
2. Contribution in society & 3.39 & 3.25 & .001 \\
3. Contribution in self-confidence & 3.68 & 3.53 & .000 \\
4. Contribution being aware of social responsibility & 3.41 & 3.30 & .008 \\
5. Contribution in being aware of personal responsibility & 3.42 & 3.35 & .110 \\
6. Contribution in using telecommunication devices & 3.28 & 3.22 & .215 \\
7. Contribution in higher education & 1.54 & 1.78 & .000 \\
8. Contribution in professional life & 3.61 & 3.40 & .000 \\
9. Contribution in various opportunities & 3.53 & 3.39 & .000 \\
10. Contribution in being shielded from the risk of poverty & 2.95 & 2.83 & .006 \\
11. Contribution in being saved from poverty & 2.35 & 2.41 & .170 \\
12. Contribution in having work & 2.19 & 2.47 & .000 \\
13. Contribution in providing continuous work and salary & 2.88 & 2.74 & .000 \\
14. Contribution in promotion at work & 2.84 & 3.08 & .000 \\
15. Contribution in basic needs & 2.34 & 2.35 & .713 \\
16. Contribution in having no work when graduating from the Open Education Faculty & 2.09 & 2.33 & .000 \\
17. Contribution in cultural needs & 2.31 & 2.40 & .028 \\
18. Contribution in having no work due to private firm preferences & 2.18 & 2.38 & .000 \\
\hline
\end{tabular}

As can be seen from Table 5. the contribution of their education in the family setting is different for males and females $(\mathrm{p}=0.000)$. The contribution for the females is more than that for males.

Another significant difference is the contribution of their education in society $(\mathrm{p}=0.001)$. This contribution of the females is more than males for this item.

The increment in the respondents' self-confidence increases with the education they received. However, this increment is more for the females than males $(\mathrm{p}=0.00)$.

Thoughts vary regarding social responsibility. The education the respondents received increases their social responsibility. This increment is more for the females than males with the difference genders being significant $(\mathrm{p}=0.008)$.

The respondents were asked if their education contributed to their awareness of personal responsibility. Both the females and the males said that they thought that the education they received contributed to their personal responsibility and, according to t test results, this contribution does not change with gender $(\mathrm{p}=0.110)$.

Both the female and the male respondents said that their education had been helpful with regard to using communication devices. There is no significant difference concerning this contribution for the females and the males with the $\mathrm{p}$ value for this t-test being calculated at 0.215 . This contribution is slightly more for the females than the males. 
The respondents' open and distance learning contribution to their higher education, professional life, opportunity in several ways, in getting work, providing continuously work and salary, promotion at work, in having no job when graduating from the Open Education Faculty, in having no work due to preferences of private firms is statistically significantly different for the female and for the male respondents. As can be seen from Table 5, all $\mathrm{p}$ values for these items are 0.000 . In addition, the males usually find their education to be more advantageous for most of these items than the females.

The item 'risk of poverty' is one of the most important among all the items for urban area residents. The female respondents believe that their education contributes in protecting them from the risk of poverty more than the males do. In addition, the $\mathrm{p}$ value calculated as a result of the $t$ test is 0.006 for this item.

The males believe that the contribution to cultural needs is more than the females do, with the t statistic being significant as $\alpha=0.05$. The $\mathrm{p}$ value is 0.028 .

The items for being saved from poverty and the contribution to basic needs are not different for the female and male respondents. The differences for these items are not statistically significant ( $\mathrm{p}=0.170, \mathrm{p}=713$ ).

\section{DISCUSSIONS and CONCLUSION}

The main results gathered from the questionnaire are as follows: working students have equal opportunities for learning while earning wages; wage differences among pre-studentship, studentship and post-studentship periods are significant; many of the alumni pointed that they are better off with regard to social welfare; the alumni are either further from poverty or they are recovering from poverty; being part of the alumni allowed them to achieve better nutrition, better clothing, and better accommodation and to reach a better place in society; have greater self-confidence; have a say regarding problems within their family; be aware of their social and individual rights and responsibilities; increase professional developments; be aware of more options for their lives and to satisfy cultural needs. These results seem similar to those obtained from Olakulein (2006) and Becker (1993) stated that there was an increase of the possibility of social life though education and there was an increase in artistic and sporting activities, respectively. Also, our results suggest common conclusions with Aderinoye and Ojokheta' study (2004) that was pointing out the increase on the number of choices people have which can be thought as a sign in social development.

In conclusion, Anadolu University Open and Distance Learning System makes important contributions to social and economic welfare, whilst helping to reduce poverty, particularly among urban area residents. Likewise in Ambre-Uva' study (2010) and Khan and Williams (2007), the ODL system made contributions to poverty alleviation. They both showed that ODL had the positive effects in reducing poverty. The system provides large numbers of people with equal, or even better, benefits of conventional face-to-face education programs, which can increase their current performance.

Thoughts and related perceptions that define the positives of the ODL system show an expected finding. Participants agree that the ODL system has made various positive contributions to their everyday lives. These results suggest common points as in Ferdousi' paper (2010) that was indicating positive effects of the open university on both adults and women by enabling them study while working in Bangladesh. As can be seen in the literature, the ODL system is of marked importance in the lives of distance learners. Considering these findings, the research and applications for the development of the ODL system should go beyond the wide framework of educational issues.

Acknowledgements: The authors wish to thank Anadolu University Scientific Research Projects (Project No: 1110E174) for the financial support given. 


\section{BIODATA and CONTACT ADDRESSES of AUTHORS}

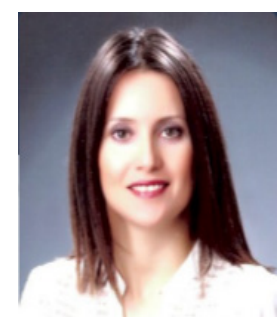

Dr. Betul KAN KILINC, is an Assoc. Prof. in Faculty of Science, Eskişehir Technical University. Dr. Kan Kılınç gained her Ph.D. in Statistics at December, 2010. Her academic interest areas are data science, supervised-unsupervised learning algorithms, data mining, nonparametric regression, multivariate statistics, open and distance learning and $\mathrm{R}$ statistical programming. She has over than 20 journal articles published in international/national indexes, 2 international book chapters, and other international/ national proceedings submitted to international meetings.

Dr. Betul KAN KILINC

Department of Statistics, Faculty of Science

Address: Eskişehir Technical University, 26470, Eskişehir, Turkey

Phone: +90222335 0580,

E-mail: bkan@eskisehir.edu.tr

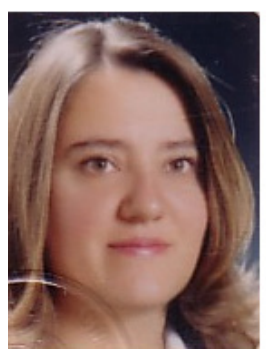

Dr. Berna YAZICI, is a Professor of Statistics in Faculty of Science, Eskisehir Technical University. Dr. YAZICI got her Ph.D. from Statistics in 2001 and became Professor in 2013. She studies and gives the courses on Design of Experiments, Regression Analysis, Statistics. She has more than 40 papers in international indexes, 2 international, 1 national book chapters and more than 50 proceeding papers. She currently works for Eskişehir Technical University, Department of Statistics

Dr. Berna YAZICI

Department of Statistics, Faculty of Science

Address: Eskişehir Technical University, 26470, Eskişehir, Turkey

Phone: +90 222335 0580,

E-mail: bkan@eskisehir.edu.tr

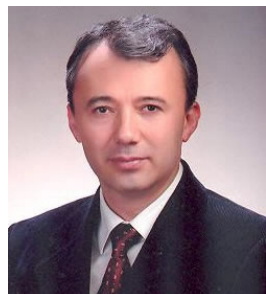

Dr. Bulent GUNSOY, is a Professor of Economy at Faculty of Economics. He completed his Ph.D. in Economics at June, 1997. His academic interest areas are microeconomics, macroeconomics, globalization, structural reforms, development economics, open and distance learning. He has 12 journal articles published in international indexes, 6 national books, 9 national book chapters and other national and international articles, papers submitted to international congress.

Dr. Bulent GUNSOY

Department of Economics, Faculty of Economics

Address: Anadolu University, 26470, Eskişehir, Turkey

Phone: +90 222335 0580,

E-mail: bgunsoy@anadolu.edu.tr

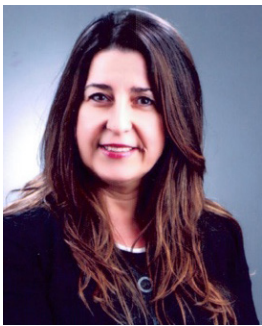

Dr. Guler GUNSOY, is a Professor of Economy at Economy Faculty, Anadolu University. Dr. Günsoy gained her Ph.D. in Economy at September, 1999. Her academic interest areas are macro economics, economic development, growth, poverty, women empowerment, open and distance learning, the effect of distance education on development. She has over than 10 journal articles published in international indexes, 3 national books, 5 national book chapters and other national and international articles, papers submitted to international meetings.

\section{Dr. Guler GUNSOY}

Department of Economics, Faculty of Economics

Address: Anadolu University, 26470, Eskişehir, Turkey

Phone: +90 2223353454 ,

E-mail: gcinier@anadolu.edu.tr 


\section{REFERENCES}

Adelman, I., Morris, C.T. (1973). Economic growth and social equity in developing countries. California: Stanford University Press. USA.

Aderinoye, R.A., Ojokheta K. (2004). Open-Distance Education as a mechanism for sustainable development: reflections on the Nigerian experience. International Review of Research in Open and Distance Learning, 5(1).

Adewarai, J.A., Adeleke, I.A., Ogundeji, R.K., \& Ahani, E.B. (2010). A statistical analysis of the performance distance learning students and the full-time students at the university of Lagos. American Journal of Business Education, 3(9), 17-22

Ambe-Uva, T., Adegbola, E. (2009). Open flexible learning as strategy for enhancing human security in Nigeria. International Journal of Education and Development using Information and Communication Technology (IJEDICT), 5(3), 148-156.

Ambe-Uva T. (2010). Open and Distance Education: A contribution to poverty alleviation and empowerment of women?Victoria Island, Lagos, Nigeria. Retrieved from http://oasis.col.org/ bitstream/handle/11599/2151/2010_Ambe-UvaTN_Contribution_to_poverty_alleviation. pdf?sequence $=1$ \&isAllowed $=\mathrm{y}$

Aukrust, O., Bjerke, J. (1995). Real Capital and Economic Growth in Norway 1900-1956. Review of Income and Wealth, 8(1), 80-118.

Bassanini, A., Scarpetta, S. (2001). The driving forces of economic growth: panel data evidence from OECD countries. OECD Economic Studies, 33(II), 9-56.

Becker, G.S. (1993). Human Capital: A theoretical and empirical analysis with special reference to education, Third Ed., Chicago: University of Chicago Press.

Breton, T.R. (2003). Education, Human Capital, and National Income. EER 2003-115, George Mason University, March 10.

Breton, T.R. (2014). Schooling and Economic Growth: What Have We Learned?. Universidad EAFIT, April 7, Columbia.

Bourguignon, F., Morrison, C. (1990). Income Distribution, Development and Foreign Trade: A Crosssectional Analysis. European Economic Review, Elsevier, 34(6), 1113-1132.

Bourguignon, F. (1995). Equity and economic growth: permanent questions and changing answers. DELTA Working Papers, 96-15.

Davies, J. (2003). Empirical Evidence on Human Capital Externalities, RBC Financial Group, EPRI Working Paper Series, 2003-5, August, Canada.

Denison, E.F. (1962). The Sources of Economic Growth in the United States and the Alternatives Before Us, New York Committee for Economic Development.

Ferdousi, N. (2010). Distance Education for Law Promotes Gender Equity in Bangladesh. Asian Journal of Distance Education, 8(1), 81-86.

Ferreira, F.H.G, Litchfield, J.A. (1998). Calm After The Storms: Income Distribution in Chile, 1987-1994. World Bank, Policy Research Working Paper, No: 1960, Washington D.C.

Gennaioli, N., La Porta R., Lopez-de-Silanes, F., \& Shleifer, A. (2013). Human capital and Regional Development. Quarterly Journal of Economics, 128(1), 105-164.

Ghadoliya, M.K. (2012). Empowering Women Through Self-Help Groups: Role Of Distance Education. www.col.org, https://www.col.org/pcf3/Papers/PDFs/Ghadolia_MK.pdf (08.09.2012)

Heckman, J., Klenow, P. (1974). Human capital policy. Working Paper, Economics Department, University of Chicago, 1997.

Holzweiss, P.C, Joyner, S.A., Fuller, M.B. (2014). Henderson S, Young R. Online graduate students' perceptions of best learning experiences, Distance Education, 35:3: 311-323, DOI: $10.1080 / 01587919.2015 .955262$

Khan, H., Williams, J.B. (2007). Poverty Alleviation through Access to Education: Can E-Learning Deliver?(U21Global Working Paper, No. 002/2006) in "Poverty, Poverty Alleviation, and Social Disadvantage: Analysis, Case Studies and Policies", Eds. C. A. Tisdell, Serials Publications, New Delhi. 
Kanwar, A.S., Margaret, T. (2001). Brave New Women of Asia: How Distance Education Changed Their Lives, The Commonwealth of Learning, Vancouver, Canada.

Mincer, J. (1974). Schooling, Experience and Earnings, NBER Books National Bureau of Economic Research, Columbia University Press, NY.

Mingati, A., Tan, J.P. (1996). The Full Social Returns to Education: Estimates Based on Countries' Economic Growth Performance. Human Capital Development Working Papers, World Bank Washington D.C.

Moore, J.L, Dickson-Deane, C., \& Galyen, K. (2011). E-learning, online learning, and distance learning environments: Are they the same? Internet and Higher Education, 14, 129-135.

Ofoegbu, I.F. (2009). Female Access To Basic Education: A Case For Open Distance Learning (ODL). Edo Journal of Counselling, 2(1).

Olakulein, F.K. (2006). Distance Education as a Women Empowerment Strategy in Africa. Turkish Online Journal of Distance Education, TOJDE, January, 7(1).

Orazem, P., Glewwe, P., \& Patrinos, H. (2007). The Benefits and Costs of Alternative Strategies to Improve Educational Outcomes. Iowa State University, Department of Economics, Working Paper, No: 7028. November.

Patrinos, H.A., Psacharopoulos, G. (2011). Education: Past, Present and Future Global Challenges. World Bank, Policy Research Working Paper 5616, March.

Polachek, S.W. (2007). Earnings Over the Lifecycle: The Mincer Earnings Function and Its Applications. Discussion Paper, IZA DP No. 3181, November.

Psacharopoulos, G. (1977). Unequal Access to Education and Income Distribution. De Economist, 125(3), 383-92.

Psacharopoulos, G., Ng, Y.C. (1992). Earnings and Education in Latin America: Assessing Priorities for Schooling Investment. World Bank Policy Research Papers, WPS No: 1056, December.

Remedios, R., Richardson, J.T.E. (2013). Achievement goals and approaches to studying: evidence from adult learners in distance education, Distance Education, 34(3),271-289. DOI: $10.1080 / 01587919.2013 .835776$

Sahin, I., Shelly, M. (2008). Considering Students' Perceptions: The Distance Education Student Satisfaction Model. Educational Technology \& Society, 11(3), 216-223.

Schultz, T.W. (1961a). Investment in Human Capital. American Economic Review, 51, 1-17.

Schultz, T.W. (1961b). Education and economic Growth. Social Forces Influencing American Education içinde N. B. Henry (eds), National Society for the Study of Education, Chicago

Shea, O.S., Stone, C., \& Delahunty, J. (2015). I feel like I am at university even though I am online. Exploring how students narrate their engagement with higher education institutions in an online learning environment, Distance Education, 36(1),41-58. DOI: 10.1080/01587919.2015.1019970

Sianesi, B., van Reenen, J. (2003) The returns to education : macroeconomics. Journal of Economic Surveys, $17(2), 157-200$.

Simsek, N. (2005). Perceptions and Opinions of Educational Technologies Related to Educational Technology. Educational Technology \& Society, 8 (4), 178-190.

Tatar, E., Zengin, Y., \& Kağızmanlı, T.B. (2015). What is the Relationship between Technology and Mathematics Teaching Anxiety? Educational Technology \& Society, 18 (1), 67-76.

Tilak, J.B.G. (1989). Education and Its Relation to Economic Growth, Poverty, and Income Distribution: Past Evidence and Further Analysis., World Bank Discussion Paper, 46.

Tsakloglou, P., Cholezas, I. (2005). Education and Inequality in Greece. IZA Discussion Paper, No: 1582, May, Germany.

Wolfe, B., Haveman, R. (2001). Accounting for the Social and Non-Market Benefits of Education, OECD/ Human Resources Development, http://www.oecd.org/innovation/research/1825109.pdf (01.05.2017). 